\title{
Studi Aklimatisasi Heosemys spinosa di Area Konservasi Ex-situ Universitas Bengkulu
}

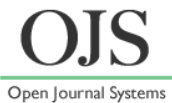

\author{
Leditiya Lestari*, Aceng Ruyani, Hery Suhartoyo \\ Pascasarjana Pendidikan IPA FKIP Universitas Bengkulu, Bengkulu \\ Jurusan Kehutanan Universitas Bengkulu, Bengkulu \\ *Email: leditiya@yahoo.co.id
}

DOI: https://doi.org/10.33369/pendipa.5.2.244-250

\begin{abstract}
[Acclimatization study of Heosemys spinosa in Ex-situ Conservation Area University of Bengkulu] This study aimed to know: a) feed composition suitable for the growth of $H$. spinosa, b) physiological conditions of $H$. spinosa during the acclimatization, $c$ ) physical conditions of $H$. spinosa during the acclimatization, d) abiotic component in ex-situ conservation area. The research method used is experimental. The results showed that: a) The rate of body weight growth in the 100\% M. paradisiaca $(P 2)$ feeding group was higher than rate of body weight growth growth in the $50 \%$ C. papaya: $50 \% \mathrm{M}$. paradisiaca (P3) and 100\% C. papaya (P1) feeding group, b) the were no abnormalities physical condition of the feeding group $100 \% \mathrm{M}$. paradisiaca (P2) and $100 \%$ C. papaya $(P 1), c)$ No egg or parasite was found in the stool of $100 \%$ M. paradisiaca feeding group (P2). There was Ascaris lumbricoides eggs found in the stool of 50\% C. papaya: $50 \% \mathrm{M}$. paradisiaca feeding group (P3) and $100 \%$ C. papaya feeding group (P1), d) soil pH in Ex-situ Conservation Area University of Bengkulu is 6,5 (fertile soil type). Soil temperature in Ex-situ Conservation Area University of Bengkulu is 2929,5C. Air humidity in Ex-situ Conservation Area University of Bengkulu is 64-79\%.
\end{abstract}

Keywords: Growth, Physiological, Physical, Heosemy spinosa, Abiotic.

\begin{abstract}
ABSTRAK
Penelitian ini bertujuan untuk mengetahui: a) komposisi pakan yang sesuai untuk pertumbuhan $H$. spinosa, b) kondisi fisiologi dan kondisi fisik $H$. spinosa selama masa aklimatisasi, dan c) kondisi lingkungan abiotik di area konservasi ex- situ UNIB. Metode penelitian yang digunakan adalah eksperimen. Hasil penelitian menunjukkan bahwa: a) kelompok pemberian pakan 100\% Musa paradisiaca (P2) menunjukkan pertumbuhan berat badan yang lebih baik daripada kelompok pemberian pakan 50\% Carica papaya : 50\% Musa paradisiaca (P3) dan kelompok pemberian pakan $100 \%$ Carica papaya (P1), b) Tidak ditemukannya kelainan kondisi fisik $H$. spinosa pada kelompok pemberian pakan $100 \%$ Musa paradisiaca (P2) dan kelompok pemberian pakan $100 \%$ Carica papaya (P1), c) Tidak ditemukannya infeksi parasit pada kelompok pemberian pakan $100 \%$ Musa paradisiaca (P2) pada hasil pemeriksaan feses. Sedangkan pada pada hasil pemeriksaan feses. kelompok pemberian pakan $100 \%$ Carica papaya (P3) dan kelompok pemberian pakan $50 \%$ Carica papaya: $50 \%$ Musa paradisiaca. ditemukan adanya infeksi telur cacing Ascaris lumbricoides, dan d) tanah di area di area konservasi ex-situ UNIB memiliki pH 6,5 dengan ketegori subur. Suhu tanah di area konservasi konservasi ex-situ UNIB yaitu $29-29,5^{\circ} \mathrm{C}$. Sedangkan kelembaban udara di area konservasi konservasi ex-situ UNIB yaitu 64-79\%.
\end{abstract}

Kata kunci: Pertumbuhan, Kondisi Fisiologis, Kondisi Fisik, Heosemys spinosa, Abiotik. 


\section{PENDAHULUAN}

Daratan Indonesia meliputi sepertiga dari daratan dunia dan berada pada dua satuan biogeografi yang unik yaitu dataran Sunda dan dataran Sahul. Dengan posisi geografi tersebut, Indonesia menampung 12-17 \% keanekaragaman hayati dunia. Indonesia tercatat sebagai negara dengan keanekaragaman kura-kura air tawar dan kura-kura darat tertinggi, diikuti Malaysia dan Papua Nugini. Dari 260 spesies kura-kura yang sudah dikenal di dunia, 85 spesies diantaranya dapat ditemukan di Asia (Ernst dan Barbour, 1989). Heosemys spinosa merupakan salah satu spesies kura-kura semi teresterial atau semi akuatik yang dapat ditemukan tersebar di wilayah Indonesia, yaitu Mentawai, Kalimantan, dan Sumatera.

Data yang diperoleh dari International Union for Conservation of Nature Resources (IUCN) menyebutkan bahwa $H$. spinosa berada dalam kategori redlist terancam punah atau endangered. Menurut Primack dan Supriatna (2004), faktor penyebab kepunahan keanekaragaman hayati yang terjadi saat ini hampir sepenuhnya dipengaruhi manusia seperti logging (pembalakan hutan), kebakaran, peningkatan populasi manusia secara cepat yang menyebabkan habitat hidup flora dan fauna yang dialih fungsikan menjadi lahan permukiman, serta perburuan yang berlebihan (overhunting) yang dikuti dengan pola konsumsi manusia. Maraknya perburuan baik untuk keperluan konsumsi maupun koleksi mempercepat laju kepunahan $H$. spinosa. Sementara itu, kura-kura memiliki daerah edar yang cukup luas yang menyebakan frekuensi pertemuan antar individupun terbilang jarang. Hal ini menyebabkan kemungkinan untuk kawin cukup langka sehingga laju pertumbuhan $H$. spinosa di alam tergolong lambat (Iskandar, 2000). Dalam keadaan demikian, strategi pelestarian yang dapat digunakan untuk melindunginya dengan menempatkannya dalam suatu lingkungan yang dapat dipantau secara berkelanjutan yang dikenal sebagai konservasi ex-situ (Primack dan Supriatna, 2004).

Universitas Bengkulu (UNIB) merupakan satu-satunya lembaga pendidikan di Bengkulu yang memiliki program konservasi kura-kura yaitu"UNIB Campus a Safe Home for Turtle". Kegiatan ini digagas oleh Bapak Dr. Aceng Ruyani, MS selaku dosen S2 IPA Fakultas Keguruan dan Ilmu Pendidikan UNIB. H.spinosa merupakan salah satu dari 5 jenis spesies kurakura yang dikonservasi di area UNIB. Angilleta
(2014) menjelaskan bahwa organisme memiliki kemampuan untuk menyesuaikan kondisi fisiologis dalam menanggapi kondisi lingkungan yang disebut aklimasi atau aklimatisasi. Kegiatan konservasi $H$. spinosa di area konservasi UNIB perlu memperhatikan kemampuan penyesuaian fisiologis atau adaptasi $H$. spinosa terhadap lingkungan baru yang dimasukinya. Penelitian ini bertujuan untuk mengetahui komposisi pakan yang pakan yang sesuai untuk pertumbuhan $H$. spinosa, mengetahui kondisi fisiologi dan kondisi fisik $H$. spinosa selama masa aklimatisasi, serta mengetahui kondisi faktor abiotik di area konservasi.

\section{METODE PENELITIAN}

\section{Waktu dan Lokasi Penelitian}

Penelitian ini dilakukan mulai bulan Maret 2017 sampai bulan Agustus 2017 bertempat di lingkungan area konservasi ex-situ kura-kura Universitas Bengkulu.

\section{Alat dan Bahan}

Bahan atau objek dalam penelitian ini adalah yaitu kura-kura $H$. spinosa serta pakan berupa Musa paradisiaca, dan Carica papaya.

Peralatan yang digunakan dalam penelitian ini adalah jaring, waring poly net, pancang kayu untuk membangun kandang. Sprinkle untuk membasahi area kandang agar terjaga kelembabannya. Nampan plastik untuk wadah pakan, Baskom plastik untuk wadah air. Timbangan digital untuk mengukur berat pakan dan berat badan kura-kura. Meteran tali dan jangka sorong untuk menghitung tebal badan, ukuran panjang, serta lebar karapaks dan plastron. Termometer infra merah untuk mengukur suhu tubuh kura-kura. Sling hygrometer untuk mengukur suhu udara. Soilmoisture untuk mengukur $\mathrm{pH}$ tanah. Soilthermometer untuk mengukur suhu tanah. Mikroskop untuk mengamati infeksi cacing pada kura-kura. Alat tulis untuk mencatat informasi yang ditemukan di lapangan. Kamera untuk dokumentasi.

\section{Pemeliharaan H. spinosa}

Sebanyak 7 ekor $H$. spinosa yang digunakan dalam penelitian ini diaklimatisasi di area konservasi ex-situ kura-kura UNIB. 7 ekor $H$. spinosa dibagi secara acak menjadi tiga perlakuan pada komposisi pakan yang berbeda di waktu yang berbeda pula selama 3 pekan. 
Tabel 1. Rancangan Penelitian

\begin{tabular}{|l|c|ll|l|}
\hline \multicolumn{1}{|c|}{ Pelakuan } & $\mathbf{n}$ & $\begin{array}{l}\text { Kode } \\
\text { Tagging }\end{array}$ & $\begin{array}{c}\text { Waktu } \\
\text { Pengamatan }\end{array}$ \\
\hline $\begin{array}{l}100 \% \text { Carica } \\
\text { papaya }\end{array}$ & 3 & $\begin{array}{l}\bullet \\
\bullet \\
\text { BHI } \\
\text { IOP } \\
\text { JKL }\end{array}$ & 3 minggu \\
\hline $\begin{array}{l}100 \% \text { Musa } \\
\text { paradisiaca }\end{array}$ & 3 & & $\begin{array}{l}\bullet \\
\bullet\end{array}$ & BIL \\
$\bullet$ & ACX & 3 minggu \\
\hline $\begin{array}{l}50 \% \text { Carica } \\
\text { papaya }+ \\
50 \% \text { Musa } \\
\text { paradisiaca }\end{array}$ & 3 & $\begin{array}{l}\bullet \\
\bullet\end{array}$ & $\begin{array}{l}\text { LML } \\
\text { BIK }\end{array}$ & 3 minggu \\
\hline
\end{tabular}

\section{Pengukuran dan Pengamatan}

Pengukuran pertumbuhan $H$. spinosa yang dilakukan meliputi pengukuran berat badan, panjang dan lebar lengkung karapaks serta plastron, panjang dan lebar karapaks serta plastron, dan tebal badan. Pengukuran dilakukan sebelum individu dipindahkan ke area konservasi ex-situ kura-kura UNIB dan setiap minggu selama masa aklimatisasi di area konservasi. Pengamatan yang dilakukan meliputi pengamatan kondisi fisik dan kondisi fisiologis H. Spinosa selama masa aklimatisasi.

Pengukuran faktor abiotik yang dilakukan meliputi pengukuran $\mathrm{pH}$ tanah, suhu tanah, dan kelembaban udara. Pengukuran dilakukan setiap minggu selama masa aklimatisasi di area konservasi.

\section{Analisa data}

Data yang diperoleh dari hasil pengukuran pertumbuhan $H$. spinosa dianalisa secara deskriptif. Data hasil pengamatan dan pengukuran disusun dalam bentuk tabel dan grafik. Pertambahan berat, panjang lebar, dan tebal badan diperoleh dari berat, panjang, lebar, dan tebal badan akhir - berat, panjang, lebar, dan tebal badan awa 1(Waldbaver 1968 dalam Melinda, 2007). Sedangkan rumus untuk parameter penelitian ini yaitu:

a. Pertumbuhan berat badan (PBB)

Pertumbuhan berat badan

$$
\begin{gathered}
\text { = beratbadanakhir } \\
\text { - beratbadanawal }
\end{gathered}
$$

c. Pertumbuhan lebar karapaks (PLK)

Pertumbuhan lebar karapaks = lebar karapaks akhir

$\%$ PLK = - lebar karapaks awal

lebar karapaks akhir-lebar karapaks awal lebar karapaks awal

d. Pertumbuhan tebal badan (PTB)

Pertumbuhan tebal badan $=$ tebal badan akhir - tebal badan awal

$$
\% \text { PTB }=\frac{\text { tebal badan akhir }- \text { tebal badan awal }}{\text { tebal badan awal }} \times 100 \%
$$

\section{HASIL DAN PEMBAHASAN}

\section{Pertumbuhan $H$. spinosa di area konservasi}

Universitas Bengkulu (UNIB)

Pertumbuhan Reversible

Pertumbuhan Berat Badan H. spinosa

Berdasarkan Diagram 1, rata-rata laju pertumbuhan berat badan tertinggi terjadi pada kelompok yang diberi pakan $100 \% \quad M$. paradisiaca sebesar 4,43\%, kemudian pada pemberian pakan 50\% C. papaya : $50 \% \mathrm{M}$. paradisiaca sebesar 2,19\%. Rata-rata laju pertumbuhan berat badan terendah terjadi pada kelompok yang diberi pakan $100 \%$ C. papaya yaitu sebesar $0,14 \%$.

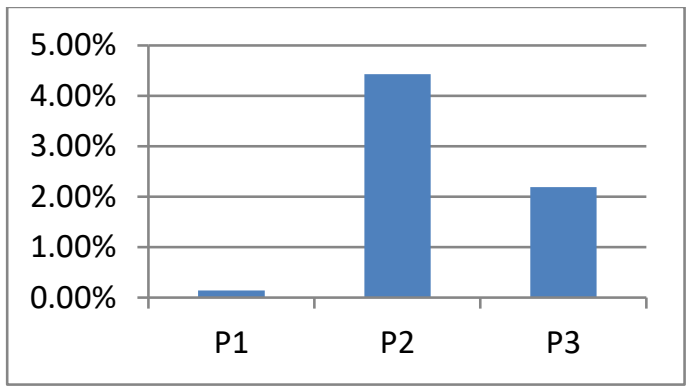

Diagram 1. Rata-rata laju pertumbuhan berat badan $H$. spinosa pada masing-masing kelompok perlakuan selama 3 pekan

Keterangan: $\mathrm{P} 1=$ Kelompok pakan $100 \% C$. papaya, $\mathrm{P} 2=$ Kelompok pakan $100 \% M$. paradisiaca, dan $\mathrm{P} 3=$ Kelompok pakan $50 \% C$. papaya : $50 \%$ M. paradisiaca

Mansur (2011) menjelaskan bahwa manfaat nutrisi pakan bagi tubuh hewan tidak hanya bermanfaat untuk memenuhi kebutuhan alat-alat tubuh yang disebut kebutuhan hidup pokok (maintenance requirements), tetapi juga digunakan untuk produksi seperti pertumbuhan. Akan tetapi kebutuhan untuk hidup pokok ini harus dipenuhi terlebih dahulu, baru kemudian kelebihan nutrisinya digunakan untuk produksi. Tidak tersedianya kebutuhan hidup pokok dalam jumlah yang cukup mengakibatkan ternak 
menjadi kurus, bahkan dapat berakibat pula pada kerugian-kerugian lain yang fatal apabila berlangsung secara terus menerus dalam jangka waktu lama. Menurut situs penghitung kalori makanan Fat Secret Indonesia, kalori yang dihasilkan dari $100 \mathrm{~g}$ M. paradisiaca sebesar 89 kalori dengan rincian 3\% lemak, 92\% karbohidrat, dan 5\% protein. Sedangkan kalori yang dihasilkan dari $100 \mathrm{~g} \mathrm{C}$. papaya sebesar 39 kalori dengan rincian 3\% lemak, $91 \%$ karbohidrat, $6 \%$ protein. Dengan jumlah yang sama, kalori yang dihasilkan $M$. paradisiaca lebih besar dari kalori yang dihasilkan $C$. papaya.

\section{Pertumbuhan Tebal Badan H. spinosa}

Tabel 2 menunjukkan bahwa laju rata-rata tebal badan $H$. spinosa pada masing-masing kelompok perlakuan selama 3 pekan tidak terdeteksi dengan alat ukur yang digunakan dalam penelitian. Hal ini dikarenakan waktu pengamatan pertumbuhan tebal badan pada penelitian ini terlalu singkat, sehingga pertumbuhan tebal badan belum dapat diamati menggunakan alat ukur yang digunakan dalam penelitian Hasil penelitian Huang (2012) menunjukkan bahwa dalam proses pertumbuhan, penambahan berat badan muncul lebih dahulu baru kemudian diikuti oleh pertumbuhan karapaks dan plastron.

Tabel 2. Rata-rata tebal badan H. spinosa masing-masing kelompok perlakuan selama 3 pekan (cm/hari)

\begin{tabular}{|l|c|c|c|c|c|}
\hline Kel & n & $\begin{array}{c}\text { Data } \\
\text { Awal } \\
\text { (A) }\end{array}$ & $\begin{array}{c}\text { Pekan } \\
\text { ke-1 } \\
\text { (B) }\end{array}$ & $\begin{array}{c}\text { Pekan } \\
\text { ke-2 } \\
\text { (C) }\end{array}$ & $\begin{array}{c}\text { Pekan } \\
\text { ke-3 } \\
(\mathbf{D})\end{array}$ \\
\hline P1 & 3 & 8,30 & 8,30 & 8,30 & 8,30 \\
\hline P2 & 3 & 8,50 & 8,50 & 8,50 & 8,50 \\
\hline P3 & 3 & 8,17 & 8,17 & 8,17 & 8,17 \\
\hline
\end{tabular}

Keterangan: $\mathrm{P} 1=$ Kelompok pakan $100 \% C$.

papaya, $\mathrm{P} 2=$ Kelompok pakan $100 \%$ M.

paradisiaca, dan $\mathrm{P} 3=$ Kelompok pakan $50 \% C$. papaya : $50 \%$ M. paradisiaca

Pertumbuhan Irreversible

Pertumbuhan Panjang Karapaks H. Spinosa

Tabel 3 menunjukkan bahwa laju rata-rata pertumbuhan pertumbuhan panjang karapaks, lebar karapaks, panjang plastron, lebar plastron, panjang lengkung karapaks, lebar lengkung karapaks, panjang lengkung plastron, dan lebar lengkung plastron $H$. Spinosa pada masingmasing kelompok perlakuan selama 3 pekan tidak terdeteksi dengan alat ukur yang digunakan dalam penelitian. Hal ini membuktikan bahwa $H$. spinosa yang digunakan dalam penilitian ini merupakan $H$. spinosa dewasa yang ukuran tubuhnyanya mendekati maksimal. Huang (2012) mengemukakan bahwa berat badan, panjang karapaks, lebar karapaks, panjang plastron dan lebar plastron berkorelasi positif dengan umur hariannya. Pertumbuhan kura-kura tahun kedua lebih lambat daripada pertumbuhan kura-kura pada tahun pertama.

Tabel 3. Rata-rata laju pertumbuhan irreversible $H$. spinosa pada masing-masing kelompok perlakuan selama 3 pekan (cm/hari)

\begin{tabular}{|c|c|c|c|c|c|}
\hline Aspek & Kel & A & B & C & D \\
\hline \multirow{3}{*}{$\begin{array}{c}\text { Panjang } \\
\text { Karapaks }\end{array}$} & P1 & 17,93 & 17,93 & 17,93 & 17,93 \\
\hline & $\mathrm{P} 2$ & 19,70 & 19,70 & 19,70 & 19,70 \\
\hline & $\mathrm{P} 3$ & 20,50 & 20,50 & 20,50 & 20,50 \\
\hline \multirow{3}{*}{$\begin{array}{c}\text { Lebar } \\
\text { Karapaks }\end{array}$} & $\mathrm{P} 1$ & 16,00 & 16,00 & 16,00 & 16,00 \\
\hline & $\mathrm{P} 2$ & 15,97 & 15,97 & 15,97 & 15,97 \\
\hline & P3 & 15,80 & 15,80 & 15,80 & 15,80 \\
\hline \multirow{3}{*}{$\begin{array}{l}\text { Panjang } \\
\text { Plastron }\end{array}$} & P1 & 16,00 & 16,00 & 16,00 & 16,00 \\
\hline & $\mathrm{P} 2$ & 17,90 & 17,90 & 17,90 & 17,90 \\
\hline & P3 & 17,93 & 17,93 & 17,93 & 17,93 \\
\hline \multirow{3}{*}{$\begin{array}{l}\text { Lebar } \\
\text { Plastron }\end{array}$} & $\mathrm{P} 1$ & 17,70 & 17,70 & 17,70 & 17,70 \\
\hline & $\mathrm{P} 2$ & 15,77 & 15,77 & 15,77 & 15,77 \\
\hline & P3 & 15,83 & 15,83 & 15,83 & 15,83 \\
\hline \multirow{3}{*}{$\begin{array}{c}\text { Panjang } \\
\text { Lengkung } \\
\text { Karapaks }\end{array}$} & $\mathrm{P} 1$ & 21,17 & 21,17 & 21,17 & 21,17 \\
\hline & $\mathrm{P} 2$ & 22,33 & 22,33 & 22,33 & 22,33 \\
\hline & $\mathrm{P} 3$ & 22,67 & 22,67 & 22,67 & 22,67 \\
\hline \multirow{3}{*}{$\begin{array}{c}\text { Lebar } \\
\text { Lengkung } \\
\text { Karapaks }\end{array}$} & $\mathrm{P} 1$ & 19,77 & 19,77 & 19,77 & 19,77 \\
\hline & $\mathrm{P} 2$ & 21,60 & 21,60 & 21,60 & 21,60 \\
\hline & P3 & 21,60 & 21,60 & 21,60 & 21,60 \\
\hline \multirow{3}{*}{$\begin{array}{c}\text { Panjang } \\
\text { Lengkung } \\
\text { Plastron }\end{array}$} & $\mathrm{P} 1$ & 16,73 & 16,73 & 16,73 & 16,73 \\
\hline & $\mathrm{P} 2$ & 18,33 & 18,33 & 18,33 & 18,33 \\
\hline & P3 & 18,07 & 18,07 & 18,07 & 18,07 \\
\hline \multirow{3}{*}{$\begin{array}{c}\text { Lebar } \\
\text { Lengkung } \\
\text { Plastron }\end{array}$} & $\mathrm{P} 1$ & 14,23 & 14,23 & 14,23 & 14,23 \\
\hline & $\mathrm{P} 2$ & 18,00 & 18,00 & 18,00 & 18,00 \\
\hline & P3 & 18,00 & 18,00 & 18,00 & 18,00 \\
\hline
\end{tabular}

Keterangan: $\mathrm{A}=$ Rata-rata data awal, $\mathrm{B}=$ Ratarata pertumbuhan pada pekan ke-1, $C=$ Rata-rata pertumbuhan pada pekan ke-2, D= Rata-rata pertumbuhan pada pekan ke-3, P1= Kelompok pakan $100 \%$ C. papaya, $\mathrm{P} 2=$ Kelompok pakan $100 \%$ M. paradisiaca, dan P3= Kelompok pakan $50 \%$ C. papaya: $50 \%$ M. paradisiaca

\section{Pemeriksaan Kondisi Fisik}

Tabel 4. Pemeriksaan fisik H. spinosa pada masingmasing kelompok perlakuan selama 3 pekan

\begin{tabular}{|c|c|c|c|c|c|}
\hline \multirow{2}{*}{ Kel } & \multirow{n}{*}{} & \multicolumn{5}{|c|}{ Pengamatan } \\
\cline { 3 - 6 } & & Mata & Hidung & Parasit & $\begin{array}{c}\text { Luka/ } \\
\text { Cacat }\end{array}$ \\
\hline P1 & 3 & 0 & 0 & 0 & 0 \\
\hline P2 & 3 & 0 & 0 & 0 & 0 \\
\hline P3 & 3 & 3 & 0 & 0 & 0 \\
\hline
\end{tabular}


Keterangan: $\mathrm{P} 1=$ Kelompok pakan $100 \% C$.

papaya, $\mathrm{P} 2=$ Kelompok pakan $100 \%$ M. paradisiaca, dan $\mathrm{P} 3=$ Kelompok pakan $50 \% C$. papaya: $50 \%$ M. paradisiaca

Tabel 4 menunjukkan bahwa tidak ditemukannya kelainan kondisi fisik $H$. spinosa pada kelompok pemberian pakan berupa $100 \%$ C. papaya $(\mathrm{P} 1)$ dan $100 \%$ M. paradisiaca $(\mathrm{P} 2)$. Sedangkan pada kelompok pemberian pakan berupa $50 \%$ C. papaya: $50 \% \mathrm{M}$. paradisiaca (P3), ditemukan kelainan pada kondisi mata $H$. spinosa selama tiga kali pengamatan.

\section{Pengamatan Kondisi Fisiologis}

Pengukuran Suhu Tubuh H. Spinosa

Rata-rata suhu tubuh $H$. Spinosa pada kelompok pemberian pakan $100 \%$ C papaya (P1) adalah $29,19^{\circ} \mathrm{C}$. Rata-rata suhu tubuh $H$. Spinosa pada kelompok pemberian pakan $100 \%$ M.paradisiaca $(\mathrm{P} 2)$ adalah $29,78^{\circ} \mathrm{C}$, dan rata-rata suhu tubuh $H$. Spinosa pada kelompok yang diberi pakan 50\% $C$. papaya : $50 \%$ $\%$. paradisiaca $(\mathrm{P} 3)$ adalah $30,13^{\circ} \mathrm{C}$.

Rata-Rata suhu tubuh H. Spinosa selama pengamatan berada di antara $29,19^{\circ} \mathrm{C}-30,13{ }^{\circ} \mathrm{C}$. Hewan eksoterm menjaga suhu tubuh melalui perilaku dan dengan modulasi kardiovaskular dari tingkat pemanasan dan pendinginan (Seebacher, 2009). Menurut Goetz (2007), pada habitat aslinya $H$. spinosa dilaporkan hidup di sungai yang dangkal dan banyak juga yang ditemukan mengembara di dalam hutan. $H$. spinosa sering ditemukan di daratan yang dingin, lembah, daerah yang gelap, dan bersembunyi di bawah sisa-sisa tanaman atau rumpun rumput. Di Area konservasi ex-situ UNIB, H. spinosa sering ditemukan berada setengah terkubur dalam galian tanah yang dibuatnya di bawah rumpun rumput atau di bawah tumpukan daundaun kering Tectona grandis (Jati) yang tumbuh di area konservasi. Jarang sekali ditemukan berada di dalam bak air yang disediakan.

\section{Pemeriksaan Feses}

Pemeriksaan feses dengan menggunakan metode uji apung bertujuan untuk mengetahui infeksi parasit pada individu $H$. spinosa. Pemeriksaan feses dilakukan pada akhir masa aklimatisasi seluruh kelompok perlakuan
Tabel 5. Hasil pemeriksaan feses H. spinosa

\begin{tabular}{|c|c|c|}
\hline Kel & Hasil Pengamatan & Infeksi \\
\hline P1 & 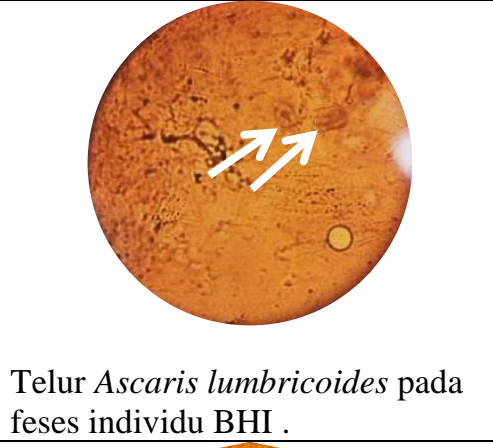 & . \\
\hline $\mathrm{P} 2$ & $\begin{array}{l}\text { Tidak ditemukannya larva } \\
\text { maupun telur cacing pada } \\
\text { pemerikasaan feses individu ACX }\end{array}$ & . \\
\hline P3 & $\begin{array}{l}\text { Telur Ascaris lumbricoides pada } \\
\text { feses individu BIK }\end{array}$ & + \\
\hline
\end{tabular}

. Keterangan: $\mathrm{P} 1=$ Kelompok pakan $100 \% C$. papaya, $\mathrm{P} 2=$ Kelompok pakan $100 \% M$. paradisiaca, dan $\mathrm{P} 3=$ Kelompok pakan $50 \% C$. papaya: $50 \%$ M. paradisiaca

Tabel 5 menunjukkan bahwa tidak ditemukannya infeksi parasit pada pemerikasaan feses individu ACX yang mewakili kelompok pemberian pakan $100 \%$ Musa paradisiaca (P2). Telur cacing ditemukan paling banyak pada individu BHI pada kelompok pemberian pakan 100\% Carica papaya (P3), dan lebih sedikit pada individu BIK pada kelompok pemberian pakan 50\% Carica papaya : 50\% Musa paradisiaca. Berdasarkan studi literatur diketahui bahwa telur cacing yang ditemukan pada merupakan individu BHI dan BIK merupakan telur cacing Nematoda (Ascaris lumbricoides). Telur Ascaris lumbricoides yang dibuahi berukuran \pm 60x45 mikron, berbentuk oval, berdinding tebal dengan 
3 lapisan berisi embrio. Telur yang tidak dibuahi berukuran $\pm 90 \times 40$ mikron, berbentuk bulat lonjong atau tidak teratur, dindingnya terdiri atas 2 lapisan dan dalamnya bergranula (Prianto et al, 2015). Menurut Dwinata et al. (2017), larutan pengapung berupa larutan garam dapat mengapungkan telur cacing kelas Nematoda (kecuali Metastrongylus sp), Kestoda serta Ookista dan Kista dari Protozoa.

Rideout et al. (1987) dalam Nugroho et al. (2017) menerangkan bahwa Infeksi nematoda parasit menimbulkan gejala klinis yang tidak spesifik, antara lain lemah, anoreksia, anemis, prolaps kloaka, dan dehidrasi. Gejala-gejala tersebut dapat timbul akibat infeksi nematoda pada saluran pencernaan yang dapat mengganggu fungsi organ pencernaan. Gangguan fungsi tersebut juga dapat mengakibatkan penurunan berat badan hingga kematian.

Rideout et al. (1987) dalam Nugroho et al. (2017) menjelaskan bahwa infeksi pada kurakura darat di penangkaran dapat terjadi karena kura-kura sudah membawa parasit dari alam liar sebelum masuk ke dalam fasilitas penangkaran. Penurunan imunitas dapat meningkatkan parasit, baik dalam jumlah maupun sifat invasive sehingga menimbulkan gangguan kesehatan.

\section{Faktor Lingkungan Abiotik}

Berdasarkan hasil pengukuran faktor abiotik di area konservasi kura-kura $H$. spinosa Universitas Bengkulu, nilai $\mathrm{pH}$ tanah yaitu 6,5. Tanah yang subur memiliki kadar $\mathrm{pH}$ yang netral atau berkisar antara 6,5-7,5. Suhu tanah di area konservasi $H$. spinosa Universitas Bengkulu yaitu 29-29,5 ${ }^{\circ} \mathrm{C}$. Sedangkan kelembaban udara di area konservasi $H$. spinosa Universitas Bengkulu yaitu 64-79\%. Valensky (2013) menjelaskan bahwa konservasi $H$. spinosa di kebun binatang Parague Republik Ceko dilakukan dengan mengkondisikan lingkungan kandang berada pada suhu $17^{\circ} \mathrm{C}\left(62.6^{\circ} \mathrm{F}\right)$ saat musim salju hingga suhu $30^{\circ} \mathrm{C}\left(86^{\circ} \mathrm{F}\right)$ pada musim panas. Sedangkan Goetz (2007) menjelaskan bahwa suhu di area konservasi yang dilakukan oleh Durrell Wildlife Conservation Trust di Jersey yaitu $22-26^{\circ} \mathrm{C}$ pada musim panas dan 24-30 ${ }^{\circ} \mathrm{C}$ (minimum pada malam hari/maximum pada siang hari).

Secara morfologi, struktur tubuh $H$. spinosa menunjukkan bahwa jenis kura-kura ini dapat hidup menahan kekeringan karena perisainya jauh lebih tebal dan lebih kuat dibandingkan dengan jenis kura-kura air tawar yang berukuran serupa. Kakinya yang bersisik tebal juga menunjukkan bahwa jenis ini memiliki cukup perlindungan untuk hidup di daratan (Iskandar, 2000). Campbell, Reece, dan Mitchell (2004) menyebutkan bahwa reaksi beberapa hewan terhadap variasi lingkungan ditunjukkan melalui modifikasi lingkungan sementaranya dengan perilaku yang koperatif .

\section{KESIMPULAN}

Kesimpulan dari penelitian ini adalah:

a) Kelompok pemberian pakan $100 \%$ Musa paradisiaca $(\mathrm{P} 2)$ menunjukkan pertumbuhan berat badan, kondisi fisik, dan kondisi fisiologis yang lebih baik daripada kelompok pemberian pakan 50\% Carica papaya : 50\% Musa paradisiaca (P3) dan kelompok pemberian pakan $100 \%$ Carica papaya $(\mathrm{P} 1)$.

b) Tidak ditemukannya kelainan kondisi fisik H. spinosa pada kelompok pemberian pakan $100 \%$ Musa paradisiaca (P2) dan kelompok pemberian pakan $100 \%$ Carica papaya (P1).

c) Tidak ditemukannya infeksi parasit pada kelompok pemberian pakan 100\% Musa paradisiaca (P2) pada hasil pemeriksaan feses. Sedangkan pada pada hasil pemeriksaan feses. kelompok pemberian pakan $100 \%$ Carica papaya (P3) dan kelompok pemberian pakan $50 \%$ Carica papaya : 50\% Musa paradisiaca. ditemukan adanya infeksi telur cacing Ascaris lumbricoides.

d) Tanah di area di area konservasi ex-situ UNIB memiliki pH 6,5 dengan ketegori subur. Suhu tanah di area konservasi konservasi ex-situ UNIB yaitu $29-29,5^{\circ} \mathrm{C}$. Sedangkan kelembaban udara di area konservasi konservasi ex-situ UNIB yaitu 64-79\%.

\section{UCAPAN TERIMAKASIH}

Dengan segala kerendahan hati penulis menyampaikan ucapan terimakasih yang setulustulusnya kepada: Partnerships for Enhanced Engagement in Research (PEER) kerjasama antara Program Pendidikan S2 IPA Universitas Bengkulu dengan University of North Carolina Greensboro (UNCG) dengan tema Developing Science and Learning Research capacity of Bengkulu University in Ex Situ Conservation of Sumateran Fresh Water and Terrestial Turtles yang didukung oleh pihak UNCG, USAID, dan NSF. 


\section{DAFTAR PUSTAKA}

Angiletta, M.J. 2014. Biochemical and Physiological Adaptations. http://angilletta.lab.asu.edu/Publications/A ngilletta\%202014.pdf Akses: 12 Febuari 2017.

Dwinata, M. I. Apsari, I. A. P., Suratma, dan Oka, I. B M. 2017. Identifikasi Parasit Cacing. https://simdos.unud.ac.id. Akses: 7 November 2018.

Emzir. 2015. Metodologi Penelitian Pendidikan Kuantiatif \& Kualitatif. Jakarta: PT. Rajawali Pers.

Ernst, C. H. dan Barbour, R.W. 1989. Turtles of The World. Smithsonian Institution Press. Washington.D.C.

Goetz, M. 2007. Husbandry and Breeding of the Spiny Turtle Heosemys spinosa (GRAY, 1931) at the Durrell Wildlife Conservation Trust. Radiata $16 \quad$ (2). https://www.researchgate.net/publication/3 05462838. Akses 7 November 2018.

Huang, Bin. 2012. Study on Growth Rhythm of Juveniles Cistolemmys Flavomarginata for One and Two Years Old 1. Physics Procedia 25 (2012) 989 - 996. Doi: 10.1016/j.phpro.2012.03.189. le online at http://www.sciencedirect.com. Akses 8 November 2018.

Iskandar, D.T .2000. Kura-Kura \& Buaya Indonesia \& Papua Nugini. Bandung: PALMedia Citra.

IUCN. 2000. Heosemys spinosa (Spiny Terrapin, Spiny Turtle, Sunburst Turtle). http://www.iucnredlist.org/details/9942/0 . Akses: 12 Febuari 2017.

Mansur, E. 2011. Pengertian Ilmu Makanan Ternak dan Zat Pakan Ternak. http://repository.ut.ac.id/4543/1/LUHT444 1-M1.pdf. Akses: 6 Januari 2018.
Nugroho, H. A, Purwaningsih. E, dan Phadmacanty, N. L. P. R. 2017. Nematoda parasit gastrointestinal pada kura-kura darat Indonesia (Manourya emys Schlegel \& Müller, 1840 dan Indotestudo forstenii Schlegel \& Müller, 1845). Pros Sem Nas Masy Biodiv Volume 3 Nomor 1. ISSN: 2407-8050 DOI: 10.13057/psnmbi/m030127. Akses: 8 Febuari 2017.

Press, Yogyakarta (Penerjemah Tjahjono Samingar). Primack, R. B. dan Supriana, J. 2004. Biologi Konservasi Edisi Revisi. Terjemahan Indrawan dan Mochamad. 2007. Jakarta: Yayasan Obor Indonesia.

Prianto, J. L. A, Darwonto, Tjahya, P. U. 2015. Atlas Parasitologi. Jakarta. Graedia Pustaka Utama

Primack, R. B. dan Supriana, J. 2004. Biologi Konservasi, edisi revisi. Terjemahan Indrawan dan Mochamad. 2007. Jakarta: Yayasan Obor Indonesia.

Seebacher, F. 2009. Commentary Responses To Temperature Variation: Integration Of Thermoregulation and Metabolism. The Journal of Experimental Biology 212 (2885-2891). doi:10.1242/jeb.024430. http://jeb.biologists.org/content/212/18/28 85.full. Akses 8 November 2018.

Velensky, P. 2013. Nine Year Effort to Breed Spiny Hill Turtle (Heosemys spinosa) Succeeds at Prague Zoo, Czech Republic. USA: Turtle Survival Alliance. Hlm. 11. 